\title{
MEMBANGUN SISTEM INVENTORYDATA BARANG (STUDI KASUS : APOTEK AN-NAFI SUMBAWA)
}

\author{
1)Rita Awaliah, ${ }^{2)}$ Shinta Esabella, 3)Yudi Mulyanto \\ 1,2,3) Program Studi Teknik Informatika, Universitas Teknologi Sumbawa \\ 1)rita.awaliah28@gmail.com, ${ }^{2}$ shintaesabella@uts.ac.id, ${ }^{3)}$ mulyanto.yudi@gmail.com
}

\begin{abstract}
ABSTRAK
Penelitian yang dilakukan bertujuan membangun sebuah sistem Inventory data barang pada Apotek yang berguna untuk memudahkan pemilik Apotek dalam mengelolah proses transaksi-transaksi yang selama ini masih dilakukan secara manual. Penelitian diawali dengan melakukan pengumpulan data, dokumentasi dan wawancara (interview), serta pengamatan secara langsung (observasi) pada tempat penelitian. Adapun data yang digunakan dalam penelitian meliputi data transaksi penjualan, transaksi pembelian dan persediaan obat. Metodologi pengembangan perangkat lunak yang digunakan dalam penelitian ini adalah metode spiral, dimana metode ini dirancang secara revolusioner dengan tahapan yang jelas dan terbuka bagi partisipasi pemesan untuk ikut serta dalam menentukan pemodelan sistem. Dengan hadirnya Sistem Inventory Data Barang pada Apotek An-Nafi Sumbawa yang dibangun menggunakan bahasa pemrograman PHP (Hypertext Preprocessor) dan database MySQL ini, dapat mempermudah pemilik dalam melakukan proses transaksi pembelian dan penjualan obat serta pengecekan ketersedian obat serta pelaporan dari hasil transaksi.
\end{abstract}

\section{Kata Kunci : Sistem Inventory, Apotek, Web, Metode Spiral}

\section{PENDAHULUAN}

Perkembangan teknologi informasi dan telekomunikasi saat ini, tidak hanya berperan penting dalam sektor pendidikan, sosial, budaya dan bisnis. Namun, peran sistem informasi sudah meluas hingga lapisan kehidupan lainnya, khususnya bidang usaha yang bergerak di sektor kesehatan. Peningkatan pelayanan dan produktivitas kinerja dalam bidang kesehatan salah satunya apotek, sangat dibutuhkan baik dalam melakukan transaksi maupun mengolah data dari hasil transaksi yang berlangsung.

Apotek An-Nafi adalah salah satu apotek yang berada di Kabupaten Sumbawa Besar, dimana pengolahan inventory data masih dilakukan secara manual. Transaksi masih dilakukan dengan cara mencatat dalam pembukuan sebagai bukti untuk pelaporan hasil transaksi kepada owner atau pemilik apotek. Selain itu, pendataan dan pengecekan data barang masih dilakukan dengan cara yang sama, sehingga pemeriksaan dan pelaporan hasil transaksi barang masuk dan barang keluar dirasa belum efektif dan efisien dalam pelaksanaannya.

Berdasarkan permasalahanpermasalahan tersebut penulis mencoba untuk membangun suatu "Sistem Inventory Data Barang Apotek An-Nafi" yang bertujuan untuk mengatasi permasalahan yang ada. Sistem tersebut dapat digunakan oleh pengguna untuk mendata ketersediaan atau stock barang apotek dengan cara menginputkan data barang melaui sistem database barang. Setiap transaksi yang terjadi akan berelasi atau saling terkait secara langsung dengan sistem database barang yang sudah di inputkan sebelumnya. Selain itu, pengguna dapat melakukan pelaporan hasil transaksi, barang masuk dan barang keluar secaralangsung dalam bentuk report harian, mingguan, ataupun bulanan. Dengan adanya report tersebut, perkembangan dan tingkat keuntungan apotek dari priode ke priode dapat langsung diketahui oleh owner atau pemilik apotek tanpa harus melakukan 
pengecekan terhadap setiap document dan struk penjualan dari hasil transaksi.

Diharapkan dengan adanya sistem inventory tersebut mampu meningkatkan produktivitas kinerja serta peningkatan pelayanan terhadap konsumen baik dalam melakukan, mengolah dan pelaporan hasil transaksi yang terjadi serta pengecekan dan pendataan ketersediaan atau stock barang dari suplier dapat dilakukan dengan lebih efektif untuk mengurangi kerugian yang ditimbulkan karena pengadaan barang dan biaya yang tidak diperlukan.

\section{METODOLOGI}

\section{Metode Pengembangan Perangkat Lunak}

Pengembangan perangkat lunak yang digunakan adalah metode spiral. Metode spiral merupakan perbaikan dari model waterfall dan prototype dengan menggabungkan keuntungan dari kedua model tersebut. Selain itu, metode spiral dirancang secara revolusioner dengan tahapan yang jelas dan terbuka bagi partisipasi pemesan untuk ikut serta dalam menentukan pemodelan sistem. Adapun tahapan-tahapan metode spiral yaitu :

\section{a. Customer Comunication}

Dalam tahap ini penelitian dilakukan dengan cara komunikasi antar pengembang dan user secara efektif untuk identifikasi masalah dan penentuan kebutuhan kerja. Komunikasi yang dilakukan untuk mendapatkan dan mengumpulkan bahan dan data penelitian sesuai dengan apa yang dibutuhkan. Dalam hal ini ada beberapa Teknik yang dilakukan yaitu wawancara, observasi dan dokumentasi.

\section{b. Planning(perencanaan)}

Dalam tahap ini penelitian dilakukan dengan mendefinisikan sumber daya, batas waktu, serta rencana dalam rancang bangun sistem yang akan dilakukan.

\section{c. Analysis}

Tahap ini dilakukan dengan melakukan analisis data dari hasil wawancara dan observasi yang telah dilakukan untuk menentukan kebutuhan alat dan bahan dalam rancang bangun sistem. Selain itu, analisis yang dilakukan berdasarkan analisis sistem yang sedang berjalan di Apotek Annafi untuk mengetahui dan menentukan masalah yang dihadapi oleh sistem yang akan diterapkan, karena merupakan dasar dalam merencanakan dan merancang sistem baru sebagai pengganti sistem manual pada Apotek An-Nafi.

d. Permodelan

Dalam tahap ini penelitian dilakukan dengan cara membuat atau merancang bangun sistem sesuai dengan identifikasi masalah dan analisis yang telah dilakukan. Permodelan data akan dibuat dengan menggunakan Data Flow Diagram (DFD) untuk menjelaskan secara rinci dan detail mengenai rancang bangun sistem yang akan dilakukan.

e. Kontruksi dan Release

Tahap ini dilakukan dengan uji coba sistem yang telah dibangun untuk mengetahui apakah sistem sudah berjalan sesuai dengan apa yang diharapkan.

\section{f. Evaluasi}

Tahap ini merupakan tahap evaluasi dari sistem yang telah dibangun dan di uji coba sebagai acuan untuk menentukan alur sistem yang berjalan sesuai dengan prosedurprosedur dalam rancang bangun sistem yang telah dilakukan.

\section{Metode Pengumpulan Data}

Dalam melakukan penelitian ini metode pengumpula data yang digunakan yaitu dengan menggunakan metode studi pustaka dan dokumentasi data dari hasil transaksi yang ada di Apotek A-Nafi.

\section{HASIL DAN PEMBAHASAN 1.}

\section{Bisnis Proses}

\section{a. Sistem Berjalan}

Adapun alur sistem yang sedang

berjalan di Apotek An-Nafi yaitu :

1. Transaksi Pembelian 


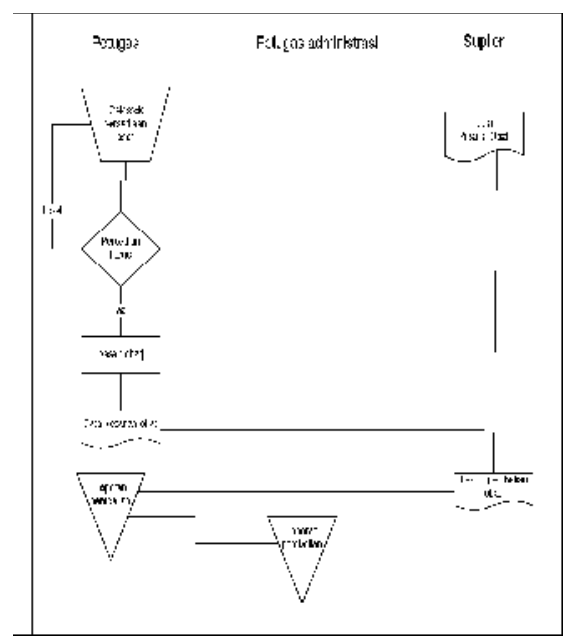

Gambar 3.1 Flow Map Transaksi Pembelian Berdasarkan Gambar 3.1 Prosedur dalam

transaksi pembelian di apotek yaitu :

1. Petugas memeriksa persediaan stok obat

2. Apabila stok obat habis maka petugas mencatat data obat dan memesan obat

3. setelah itu data pesanan obat dikirim ke suplier

4. Setelah data pesanan obat diterima suplier mengirimkan kembali obat dan data pesanan obat

5. Petugas kemudian membuat laporan data pesanan obat ke dalam data pembelian obat

6. Setelah itu petugas melaporkan ke pemilik apotek

1. Transaksi Penjualan

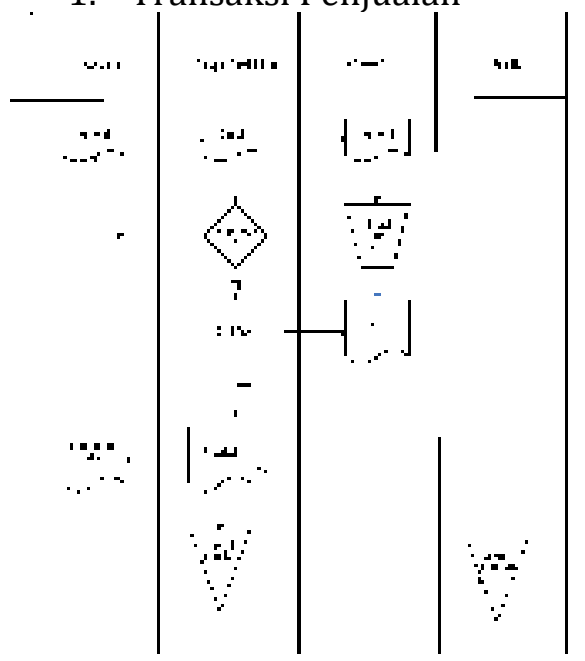

Gambar 3.2 Flow Map Transaksi

Penjualan
Berdasarkan Gambar 3.2 berikut ini prosedur transaksi penjualan pada Apotek An-Nafi yaitu :

1. Konsumen membawa data obat kemudian diberikan kepada petugas administrasi

2. Petugas administrasi memberikan kepada apoteker

3. Apoteker menyediakan obat dan diserahkan kembali kepada petugas administrasi untuk di data

4. Setelah itu jika konsumen setuju dengan harga, petugas kemudian memproses dan mencetak faktur penjualan

5. Petugas administrasi kemudian memberikan obat dan faktur kepada konsumen setelah membayar

6. Petugas kemudian mencatat hasil transaksi ke dalam laporann penjualan

7. Setelah laporan selsesai petugas melaporkan hasiontransaksi kepada pemilikn apotek.

b. Sistem Yang Diusulkan

Berdasarkan identifikasi masalah yang telah dilakukan,. Adapun alur kerja sistem yang di usulkan yaitu :

\section{Transaksi Pembelian}

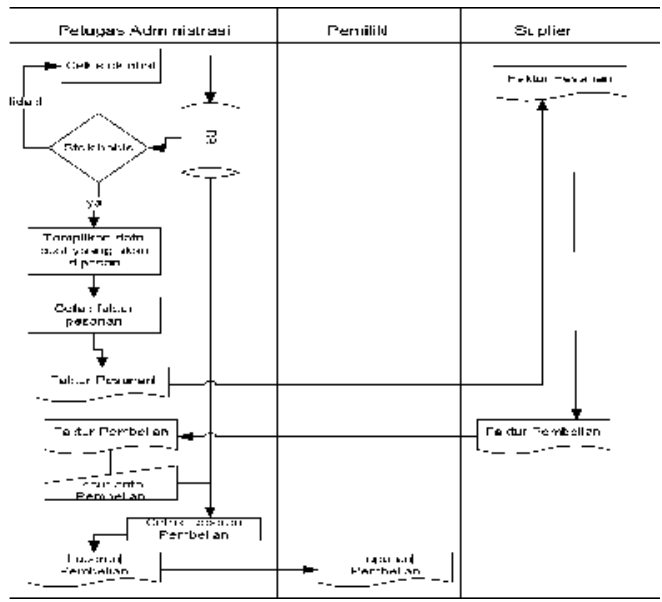

Gambar 3.3 Flow Map Transaksi

Pembelian Yang Di usulkan

Berdasarkan Gambar 3.3 berikut ini alur kerja sistem dalam transaksi pembelian yang akan di usulkan yaitu :

1. Petugas administrasi menegecek stok obat dengan menginputkan data obat yang di inginkan

2. Jika stok obat berkurang maka 
data obat akan ditampilkan kemudian dicetak

3. Setelah itu faktur pesanan obata yang dicetak di kirim ke suplier

4. Setelah suplier menerima faktur pesanan obat maka suplier mengirimkan faktur pembelian obat bersamaan dengan obat yang di pesan

5. Setelah petugas administrasi menerima faktur pembelian, petugas menginputkan kembali data pembelian obat sebagai laporan pembelian

6. Setelah itu laporan pembelian dilaporkan kembali kepada pemilik Apotek.

2. Transaksi Penjualan

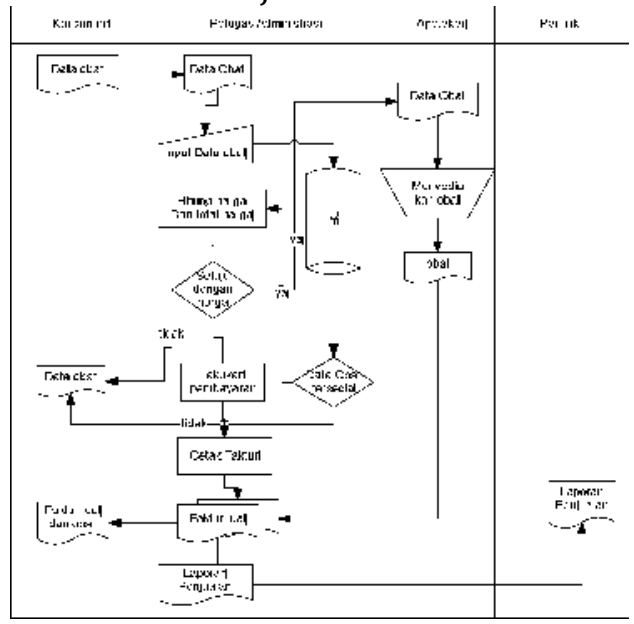

Gambar 3.4 Flow Map Transaksi Penjulan Obat yang Di usulkan

Berdasarkan Gambar 3.4 berikut ini alur kerja sistem dalam transaksi penjualan yang akan di usulkan yaitu :

1. Konsumen memberikan data obat ke petugas administrasi

2. Petugas administrasi menginputkan data ke sistem untuk menghitung harga dan total harga yang kan di bayarkan

3. Jika konsumen menyetujui harga maka data obat akan di berikan ke apoteker

4. Apoteker menyedikan obat dan diberikan kembali ke petugas administrasi

5. Petugas administrasi memproses data dan mencetak faktur

6. Faktur jual dan obat diberikan kepada konsumen

7. Dari hasil transaksi akan dijadikan sebagai laporan penjualan

8. Petugas administrasi kemudian melaporkan hasil transaksi penjualan kepada pemilik apotek.

\section{Diagram Konteks}

Berikut ini gambar diagram konteks sistem inventory data barang apotek Annafi yaitu : 


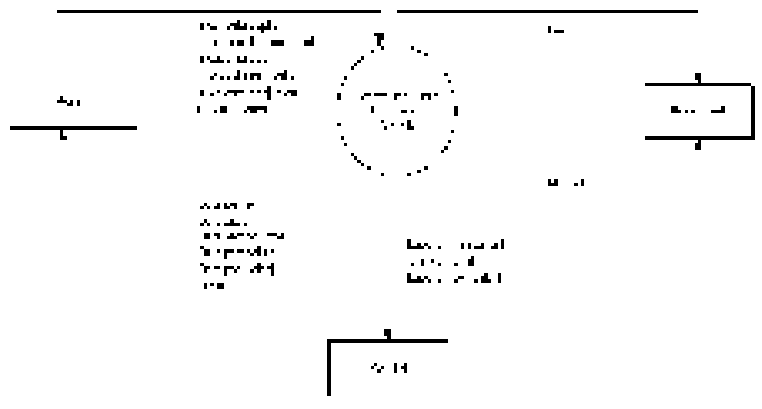

Gambar 3.5 Diagram Konteks

\section{Data Flow Diagram (DFD)}

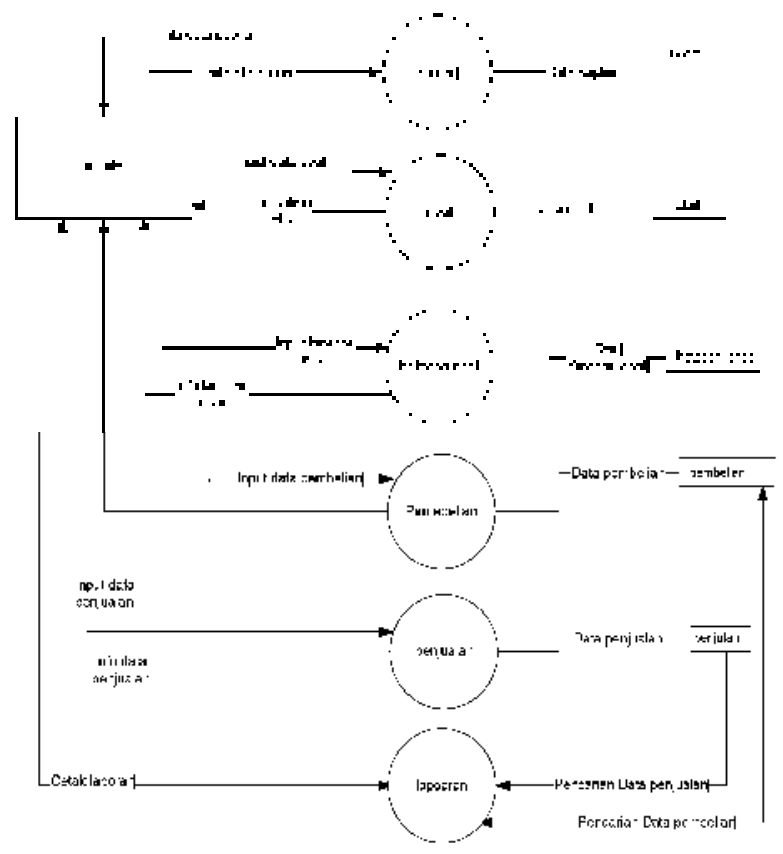

Gambar 3.6 DFD Level 0

Berdasarkan Gambar DFD Level 0 sistem inventory data barang apotek menggambarkan tentang semua alur kerja sistem yang akan dibangun.

\section{Entity Relationship Diagram (ERD)}

\section{Entity Relationship Diagram}

digunankan untuk melihat hubungan antara entitas yang terdapat dalam Sistem
$E R D$ yang terdapat dalam sistem pengelolaan data apotek :

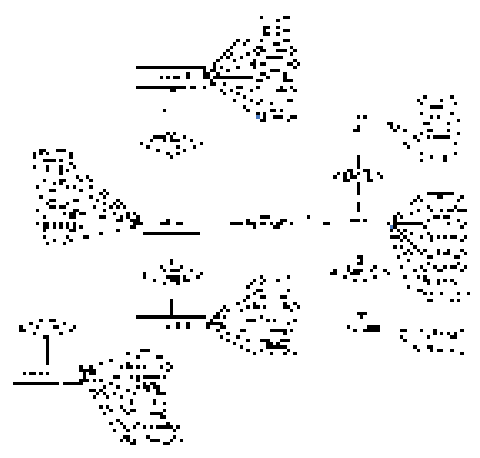

Gambar 3.7 Entity Relationship Diagram (ERD)

5. Rancangan Struktur Database

Berikut ini rancangan database sistem yang diusulkan yaitu :

a. Admin

label 3.1 Admin

\begin{tabular}{||l||l|c|l|l|}
\hline No. & Field & Type & Length & Extra \\
\hline \hline $1 \cdot$ & Id & Int & 11 & primary \\
\hline $2 \cdot$ & username & varchar & 100 & \\
\hline \hline$\cdot \cdot$ & password & password & 100 & \\
\hline $4 \cdot$ & level & int & 1 & \\
\hline $5 \cdot$ & nama & varchar & 100 & \\
\hline $6 \cdot$ & alamat & text & & \\
\hline $7 \cdot$ & No_hp & varchar & 15 & \\
\hline
\end{tabular}

b. Tabel Suplier

Tabel 3.2 Suplier

\begin{tabular}{||l||l|c||c||c|}
\hline No & Field & Type & Length & Extra \\
\hline $1 \cdot$ & Id & Int & 11 & Primary \\
\hline $2 \cdot$ & nama & varchar & 30 & \\
\hline $3 \cdot$ & alamat & text & & \\
\hline $4 \cdot$ & telp & varchar & 15 & \\
\hline
\end{tabular}

c. Obat 
Tabel 3.3 Obat

\begin{tabular}{|c|l|l|c|r|}
\hline No & \multicolumn{1}{|c|}{ Field } & Type & Length & Extra \\
\hline 1 & Id_obat & Int & 11 & primary \\
\hline 2 & Nama_obat & varchar & 30 & \\
\hline 3 & No_batch & varchar & 15 & \\
\hline 4 & Id_jenis & int & 11 & \\
\hline 5 & stock & char & 3 & \\
\hline 6 & Tgl_masuk & date & & \\
\hline 7 & Tgl_kadaluarsa & date & & \\
\hline
\end{tabular}

d. Jenis Obat

Tabel 3.4 Jenis Obat

\begin{tabular}{|c|l|c|c|c|}
\hline No & \multicolumn{1}{|c|}{ Field } & Type & Length & Extra \\
\hline 1 & Id_jenis & Int & 11 & primary \\
\hline 2 & Jenis_obat & varchar & 20 & \\
\hline
\end{tabular}

e. Pembelian

Tabel 3.5 Pembelian

\begin{tabular}{|c|l|c|c|c|}
\hline No & \multicolumn{1}{|c|}{ Field } & Type & Length & Extra \\
\hline 1 & Id & Int & 11 & Primary \\
\hline 2 & no_faktur & Int & 10 & \\
\hline 3 & Tgl_pembelia & date & & \\
\hline 4 & Nama_obat & Varchar & 30 & \\
\hline 5 & No_batch & Varchar & 15 & \\
\hline 6 & Harga & Double & & \\
\hline 7 & Jumlah & Int & 3 & \\
\hline 8 & Total_Harga & double & & \\
\hline
\end{tabular}

f. Penjualan

Tabel 3.6 Penjualan

\begin{tabular}{|c|l|c|c|c|}
\hline $\begin{array}{c}\text { N } \\
\mathbf{o}\end{array}$ & \multicolumn{1}{|c|}{ Field } & Type & Length & Extra \\
\hline 1 & Id_penjualan & Int & 11 & Primary \\
\hline 2 & Faktur & Int & 10 & \\
\hline 3 & Tanggal & date & & \\
\hline & & & & \\
\hline
\end{tabular}

8 Total_Harga double

g. Penjualan Obat

Tabel 3.7 Penjualan Obat

\begin{tabular}{|c|l|c|c|c|}
\hline No & \multicolumn{1}{|c|}{ Field } & Type & Length & Extra \\
\hline 1 & Id & Int & 11 & primary \\
\hline 2 & Nama_obat & $\begin{array}{r}\text { Varcha } \\
\mathrm{r}\end{array}$ & 100 & \\
\hline 3 & harga & Double & & \\
\hline 4 & jumlah & Int & 11 & \\
\hline 5 & Total & Double & & \\
\hline 6 & Id_penjualn & Char & 32 & \\
\hline 7 & $\begin{array}{l}\text { Temp_penj } \\
\text { u alan }\end{array}$ & Char & 32 & \\
\hline
\end{tabular}

\section{Rancangan User Interface}

a. Tampilan Input Login

Rancangan tampilan input login merupakan rancangan untuk menampilkan password dan username admin untuk mengakses sistem yang akan dibuat.

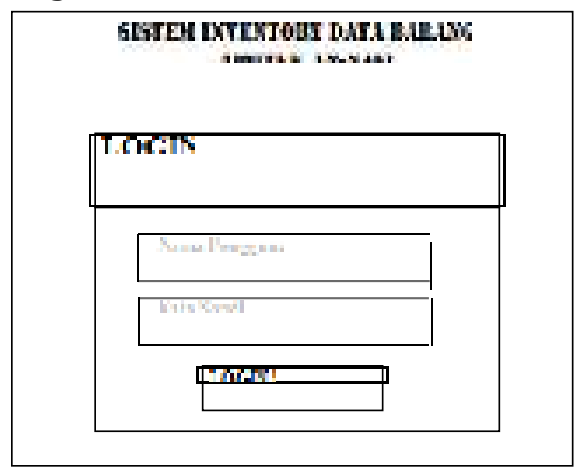

Gambar 3.8 Tampilan Input Login

b. Tampilan Input Suplier

Rancangan tampilan tambah suplier merupakan rancangan sistem untuk mengisi data-data suplier yang ada di Apotek AnNafi. 


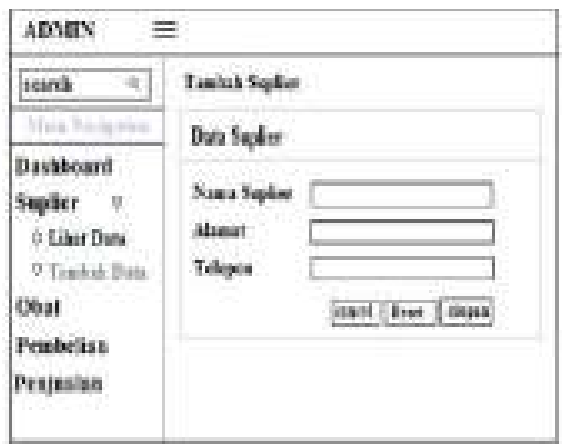

Gambar 3.9 Tambah Suplier

c. Tampilan Input Obat

Rancangan tampilan tambah data obat merupakan rancangan tampilan untuk mengisi atau menambah data obat apotek.

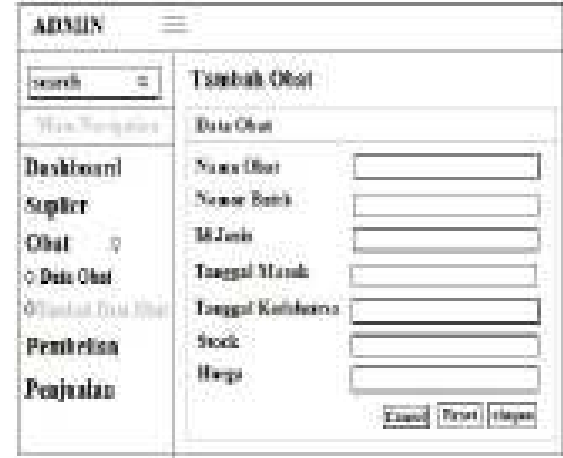

Gambar 3.10 Tampilan Tambah Data Obat

d. Tampilan Input Pembelian

Rancangan input pembelian merupakan rancangan untuk menambah dan me ngisidata pembelian obat dari suplier apotek.

\begin{tabular}{|c|c|c|}
\hline \multicolumn{3}{|l|}{ ADMII } \\
\hline send 9 & \multirow{2}{*}{\multicolumn{2}{|c|}{$\begin{array}{l}\text { Tembah Penoetian } \\
\text { Daa Puctwa }\end{array}$}} \\
\hline 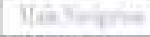 & & \\
\hline \multirow{8}{*}{ 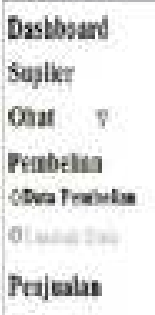 } & \multirow{8}{*}{ 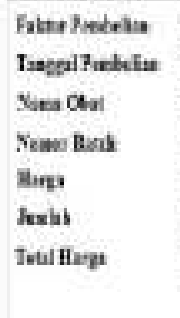 } & \\
\hline & & \\
\hline & & \\
\hline & & \\
\hline & & \\
\hline & & \\
\hline & & \\
\hline & & 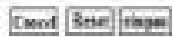 \\
\hline
\end{tabular}

Gambar 3.11 Tampilan

Tambah

Pembelian

e. Tampilan Input Transaksi Penjualan

Rancangan input traansaksi penjulan merupkan rancangan tampilan untuk melakukan transaksi penjualan obat yang ada di apotek An-Nafi.

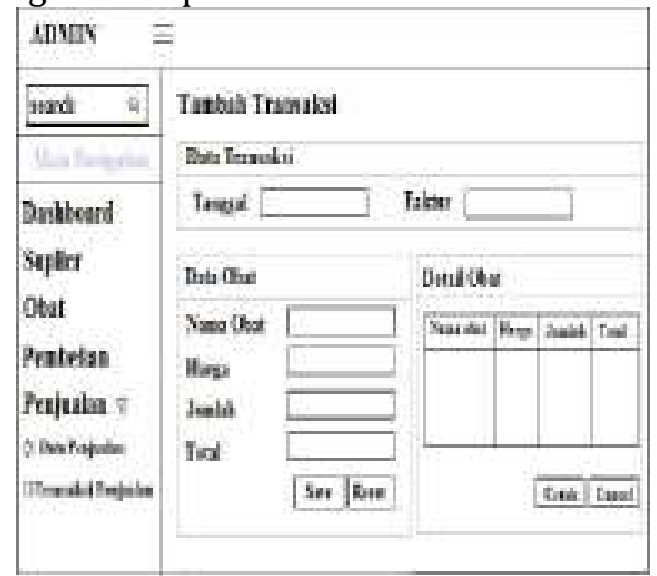

Gambar 3.12 Tampilan Transaksi Penjualan

f. Tampilan Dashboard

Rancangan tampilan dashboard merupakan rancangan tampilan untuk halaman utama (home page) sistem saat admin mengakses sistem.

\section{S S N 2527-970x}




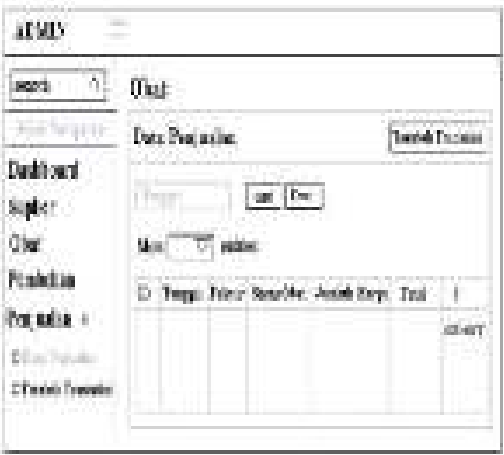

Gambar 3.17 Tampilan

Output

Lihat Data Penjualan

\section{Implementasi Sistem}

a. Implementasi Tampilan

nachhnard

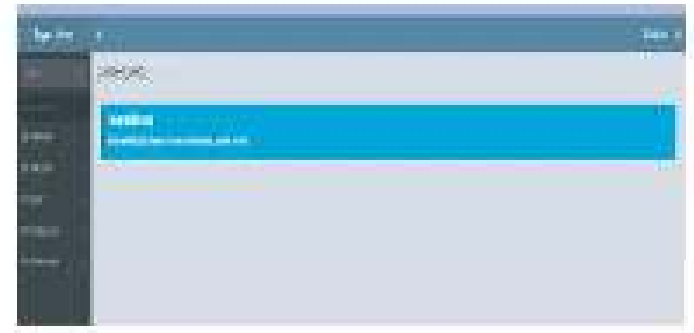

Gambar 3.18 Implementasi Tampilan

\section{Dashboard}

Tampilan dashboardyang

merupakan halaman utama saat admin berhasil mengakses sistem.

b. Implementasi Tampilan Output Suplier

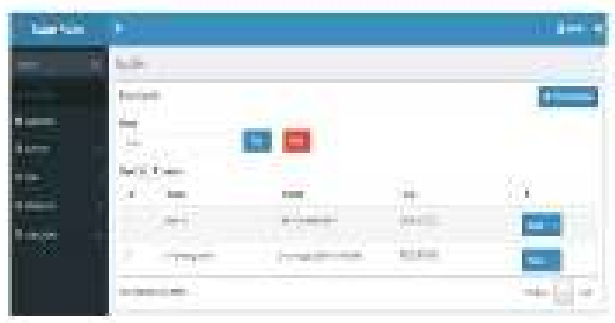

Gambar 3.19 Implementasi Tampilan Output Suplier

Tampilan output suplier yang berfungsi untuk menampilkan data- data suplier.

c. Implementasi Tampilan OutputObat

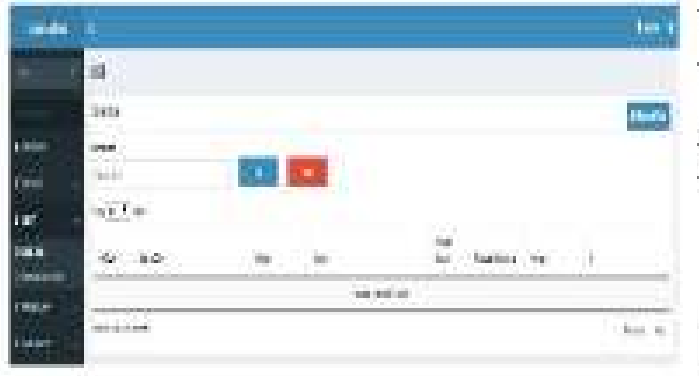

Gambar 3.20 Implementasi Tampilan Ouput Obat

Gambar merupakan implementasi tampilan output obat merupakan implementasi sistem dari form obat yang berfungsi untuk menampilkan data-data obat apotek.

\section{d. Implementasi Tampilan Output Pembelian}

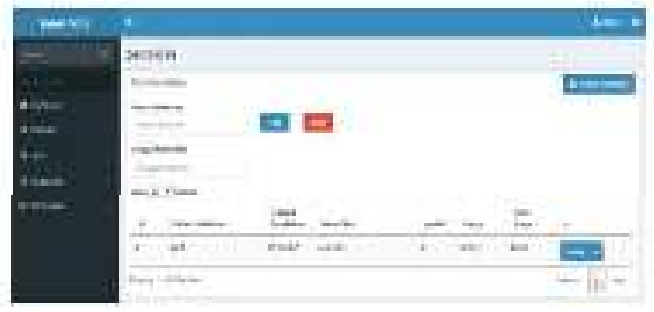

Gambar 3.21 Implementasi Tampilan OutputPembelian

Gambar implementasi form output pembelian yang berfungsi untuk mengisi data-data pembelian obat apotek.

e. Implementasi Tampilan OutputPenjualan

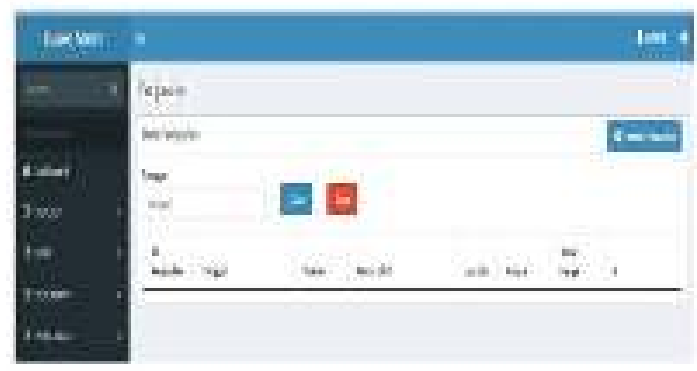

Gambar 3.22 Implementasi Tampilan OutputPenjualan

Gambar implementasi outputpenjualan yang berfungsi untuk menampilkan datadata dari hasil transaksi yang berlangsung di apotek. 


\section{KESIMPULAN DAN SARAN}

\section{Kesimpulan}

Sistem inventory data barang apotek An-Nafi Sumbawa telah berhasil dibangun dengan menggunakan bahasa pemrograman PHP (Hypertext Preprocessor) dan database MySQL. Dengan sistem yang telah diimplementasikan pada Apotek An-Nafi ini dapat digunakan untuk mempermudah pemilik dalam melakukan proses transaksi pembelian dan penjualan obat serta pengecekan ketersedian obat serta pelaporan dari hasil transaksi-transaski yang berlangsung.

\section{Saran}

Berdasarkan sistem yang dibangun adapun saran yang penulis sampaikan untuk memudahkan dalam pengembangan sistem yaitu :

1. Dalam pengembangan sistem selanjutnya diharapkan pihak apotek menyediakan media penghubung berupa barcode readeryang memudahkan dalam meng-inputkan data obat oleh pengguna sistem.

2. Sistem yang dibangun bersifat stand alone diharapkan bisa dikembangkan menjadi sistem berbasis website dan mobile yang memudahkan penggunanya dalam melakukan transaksi dan pemesanan obat.

3. Laporan yang digunakan hanya laporan stok obat, pembelian dan penjualan diharapkan bisa dikembangkan dalam menangani pelaporan data obat kadaluarsa atau sudah tidak layak untuk dijual dan digunakan.

\section{DAFTAR PUSTAKA}

Dewi, Lusiana Citra.(2013). "Sistem informasi pembelian, persediaan, dan penjualan untuk Apotek". dalam jurnal Comtech, Vol. 4 No. 1, hlm. 434

Pressman, Roger.s. (2012). Rekayasa Perangkat Lunak. Yogyakarta: Andi

Republik Indonesia, (2017). Peraturan Menteri Kesehatan Tentang Apotek. Jakarata : kementerian Kesehatan.

S. Ardy, Bagus. "Sistem Informasi Persediaan Obat Pada Apotek Patra Farma Jepara". dalam jurnal sistem informasi

Saputra, Antoni. (2015). “ Sistem Informasi Persediaan Obat Pada Apotek Nayla”. Skripsi. Palembang : Program Sarjana Komputer Universitas Gunadar 